\title{
REASONS FOR SEEKING ORTHODONTIC TREATMENT: A PILOT STUDY
}

A.A.A. Abdullah, Z. Yassin, N. Zamzam. Reasons for seeking orthodontic treatment: A pilot study. Annal Dent Univ Malaya 2001; 8: 13-19.

\section{ABSTRACT}

This pilot survey was conducted to determine the main reason and the motivating factors which, influence patients in seeking orthodontic treatment. 115 patients aged 11-30 years old were taken from the orthodontic waiting list at the Dental Faculty, University Malaya dated December 1999 - May 2000. A structured questionnaire was designed and the survey of patients was carried out using the telephone. The desire to have a better dental appearance was the main reason $(65 \%)$ given by patients who were seeking orthodontic treatment. The most important motivating factor that influences patients in seeking orthodontic treatment was to attain straight teeth (48\%). In conclusion, patients seek orthodontic treatment mainly due to psychological reason, which is to improve dental appearance and aesthetic. Perceived needs of an orthodontic patient should also be taken into consideration before commencing orthodontic treatment to increase chances of mutually satisfying result for both the orthodontist and patient.

Key words: Orthodontic treatment, reasons, motivating factors.

\section{INTRODUCTION}

The objective for undergoing orthodontic treatment is to improve dental occlusion, which, could result in a good functioning and aesthetically pleasing dentition in harmony with the face (1). Many studies have shown that problems associated with malocclusion such as traumatic occlusion, temporomandibular joint pain, periodontal disease or caries might resolve after orthodontic therapy (2).

Various reasons and factors, which influence patients in seeking orthodontic treatment, had been reported in a number of previously published studies (3-7). Social psychological impact to any malocclusion whether noticed by the patient himself or by other people such as low self-esteem, frequent teasing experiences and dissatisfaction to appearance may develop the desire for orthodontic treatment $(6,7)$. Self-concept, self-image, status, pride, discomfort and concern for future oral health are but a few reasons for a person to decide for orthodontic treatment (3).

Parents and dentists are likely to play an important role in initiating and motivating patients in seeking for orthodontic treatment $(4,5,8)$. Demographic background of a patient such as gender, age, socio-economic status,
Original Article

A.A.A. Abdullah ${ }^{1}$, Z. Yassin' ${ }^{2}$, N. Zamzam²
'Faculty of Dentistry,
National University of Malaysia,
50603 Kuala Lumpur
2Department of Children's Dentistry \& Orthodontics,
Faculty of Dentistry, University of Malaya,
50603 Kuala Lumpur
Corresponding author - Zafarina Mohamed Yassin

dental attendance frequency and familiarity of orthodontic appliance may also affect patient's perception to orthodontic treatment (4-7,9-11).

The aim of this pilot study was to determine the reasons and motivating factors, which stimulate or influence patients in seeking orthodontic treatment at the Faculty of Dentistry, University of Malaya (FDUM).

\section{MATERIALS AND METHODS}

\section{The Questionnaire}

This pilot survey was conducted using a structured questionnaire (Figure 1). Most of the questions in this study were taken from previously published studies (4-7).

The structured questionnaire consisted of two main parts. Part 1 consisted of four questions on patient's demographic data, which are the sex, age, ethnic group and dental attendance frequency. Ethnic consideration is important as this survey was done in a multi-racial country.

Part 2 of this questionnaire comprised ten questions involving psychosocial aspect of patients including dental awareness (4), dental satisfaction (5), effect of dental anomalies (4), teasing experience (6), factors which may influence patients in seeking treatment, main reason for seeking treatment and expected social changes once orthodontic therapy is completed (7).

\section{The Subjects and Survey}

Outpatients who attend FDUM for treatment will normally be seen by a dental officer in-charge in the Primary Care Unit (Bahagian Rawatan Utama - BRU) during their first visit. Patients who requested for, or considered to require orthodontic treatment have their names placed on the orthodontic screening waiting list. These patients will be seen by dental students or by the lecturers/orthodontists to determine the suitability for orthodontic treatment. Upon completion of the 


\section{Bahagian 1 (Part 1)}

1. Jantina:
Gender: $\begin{aligned} & \text { Perempuan } \\ & \text { Female }\end{aligned} \begin{aligned} & \text { Lelaki } \\ & \text { Male }\end{aligned}$

2. Umur: Age:
(A) 8 - 12 tahun

(B) 13 - 19 tahun

(C) $20-30$ tahun

(D) 31 - 40 tahun

(E) $\geq 41$ tahun
3. Bangsa: Ethnic:<smiles>C1CCCCC1</smiles>
Melayu Malay

India Indian
Cina Chinese

Lain-lain Others

4. Kekerapan mengunjungi doktor gigi : Frequency in dental attendance
(A) 6 bulan sekali 6 monthly
(B) 1 tahun once yearly
(C) bila perlu sahaja when necessary only

\section{Bahagian 2 (Part 2)}

1. Adakah anda mempunyai gigi yang tidak tersusun? Do your teeth have any irregularities?
Ya (yes)
Tidak (no)

2. Sila nilai penampilan pergigian anda ? Please assess your own dental appearance?
(A) Baik (good)
(B) Sederhana (average)
(C) Buruk (bad)

3. Pernahkah anda diejek disebabkan penampilan gigi anda? Have you ever been teased due to your dental appearance?
(A) selalu (always)
(B) kadang-kadang ( sometime)
(C) tidak pernah (never)

4. Siapakah orang pertama yang perasan kewujudan keganjilan gigi anda?

Who first noticed the presence of your dental anomalies?
(A) Sendiri (self)
(D) Doktor gigi (dentist)
(B) Ibu (mother)
(E) Lain-lain (others)
(C) Bapa (father)

5. Siapakah yang mencadangkan rawatan ortodontik kepada anda?

Who suggested you orthodontic treatment?
(A) kaum keluargal kawan-kawan (relatives/friends)
(B) sendiri (self)
(C) doktor gigi ( dentist )

6. Pada pendapat anda, setelah gigi anda telah dibetulkan, bahagian manakah didalam hidup anda yang akan berubah?

Do you think after your teeth have been straightened, which following area/areas of your life will be altered?
- Peluang kerjaya
ya (yes)
tidak (no)
(career opportunities)
tidak pasti (not sure)

$$
\begin{array}{cc}
\text { - Interaksi sosial } & \square \text { ya (yes) } \square \text { tidak (no) } \\
\text { (social interaction) } & \square \text { tidak pasti (not sure) } \\
\text { - Keyakinan diri } & \square \text { ya (yes) } \square \text { tidak (no) } \\
\text { (confidence) } & \square \text { tidak pasti (not sure) }
\end{array}
$$

7. Di antara sebab-sebab berikut, yang manakah sebab yang paling tepat menggambarkan sebab anda mendapatkan rawatan?

Which one of the following factors, most accurately describe the reason for you in seeking treatment?

(A) orang lain juga memakai aplian (others were wearing an appliance)

(B) doktor gigi anda mancadangkanya demi kesihatan pergigian (Your dentist recommended it in the interest of dental health)

(C) untuk memperbaiki penampilan gigi anda (to improve appearance of teeth)

(D) ibu mahu anda mendapatkan rawatan ( your mother wants you to have treatment)

8. Yang manakah antara faktor berikut merupakan faktor paling penting yang mendorong anda mendapatkan rawatan ortodontik?

Which one of the following factors is the most important factor in seeking orthodontic treatment?

(A) mendapatkan gigi yang tersusun lurus (attain straight teeth)

(B) meningkatkan kecantikan muka (enhance facial appearance)

(C) meningkatkan kesihatan pergigian (improve dental health)

(D) memperbaiki pertuturan (improve speech)

(E) meningkatkan keyakinan diri (enhance self-confidence)

(F) memperbaiki pengunyahan (improve chewing) 
orthodontic screening, the patients will then be referred to various groups of clinicians for appropriate orthodontic management.

Subjects for this survey were chosen from the orthodontic waiting list for the period of $15^{\text {th }}$ December 1999 until $15^{\text {th }}$ May 2000. This survey was carried out by a telephone interview and with the duration of each call being approximately 5 minutes. Out of 138 patients in the waiting list, only 115 subjects could be contacted during the survey period. No systematic effort was made to stratify the subjects, as the total number was limited. Subjects were only included in this survey if they have not undergone any kind of orthodontic treatment. All the subjects interviewed were highly cooperative, thus, making the response rate to $100 \%$.

\section{The Pre-test}

A pre-test of the questionnaires was conducted prior to the actual survey. The first five subjects who were contacted had participated in the pre-testing of the original questionnaires. These five subjects understood all the questions.

\section{RESULTS}

A total of 110 subjects aged between 11-30 years old were included in the study. Results were analysed descriptively for:

1. Demographic data of the patients

2. The main reason and factors that influence patients in seeking orthodontic treatment

\section{Part 1-Demographic data of patients}

The majority of the patients interviewed (Table I) were females (61\%) and adolescents aged between 1319 years old $(67 \%)$. Mean age of this sample was 17 years old. The proportions of Malay and Chinese patients were equal (38\%). Indians made up $21 \%$ of the total while the rest were from other ethnic groups.

Table 1: Demographic data of the subjects interviewed (Part 1 - questions 1,2,3,4)

\begin{tabular}{llc}
\hline DEMOGRAPHIC DATA & $\begin{array}{c}\text { PERCENAGE } \\
(\%)\end{array}$ \\
\hline Gender & Male & 39 \\
& Female & 61 \\
Age group & 8-12 years old & 11 \\
& $13-19$ years old & 67 \\
& 20-30 years old & 22 \\
Ethnic group & Malay & 38 \\
& Chinese & 38 \\
& Indians & 21 \\
Dental & & 12 \\
attendance & Once yearly & 14 \\
frequency & When necessary only & 74 \\
& Others & 3 \\
\hline
\end{tabular}

Table 2: Factors, which influence patients in seeking orthodontic treatment (Part 2 - questions 1,2,3,4,5)

\section{FACTORS} PERCENTAGE

Awareness of

dental anomalies

Yes

No

99

Assessment of own dental appearance

Good

Average

Bad

68

Teasing experience

Always

Sometimes

Never

First person to notice patient's dental anomalies

Self

Mother

Father

Dentist

Others

46

29

8

3

14

First person to suggest

Family/Friends

Self

Dentist

Regarding patient's dental attendance frequency, only $12 \%$ of the respondents regularly visit their dentists every 6 months while majority of the patients (74\%) visit their dentists only when necessary.

\section{Part 2- Reason \& motivating factors which influence patients in seeking orthodontic treatment}

Almost all patients (99\%) were aware that they had dental irregularities (Table II). The majority of the patients $(68 \%)$ assessed their dental appearance as average. Only $5 \%$ of the patients mentioned that they had always been teased due to their dental irregularities. Majority of the patients $(46 \%)$ stated that they themselves were the first to notice their dental anomalies while $29 \%$ of the respondents said that their mothers were the first to point out their dental problems. Only a few (3\%) noted that it was their dentist who first alerted the anomalies to them. Most of the respondents (61\%) sought orthodontic treatment following suggestions from their family and friends; dentist referral constituted only $9 \%$ (Table II). Most of the patients $(75 \%)$ felt that their confidence and self-esteem would be increased if their teeth were straightened, $64 \%$ stated that their social life would be improved while $43 \%$ believed that their career opportunities and prospect would be brighter (Figure 2). Most of the patients $(65 \%)$ stated that the main reason for seeking orthodontic treatment was to improve their own dental appearance (Figure 3). Some of the patients (18\%) actually followed their mothers' wishes in obtaining orthodontic treatment. Attaining straight teeth was cited the most important motivating factor in almost half $(48 \%)$ of the respondents (Figure 4). Second in the list was to improve dental health $(20 \%)$ and to enhance selfconfidence $(20 \%)$. 


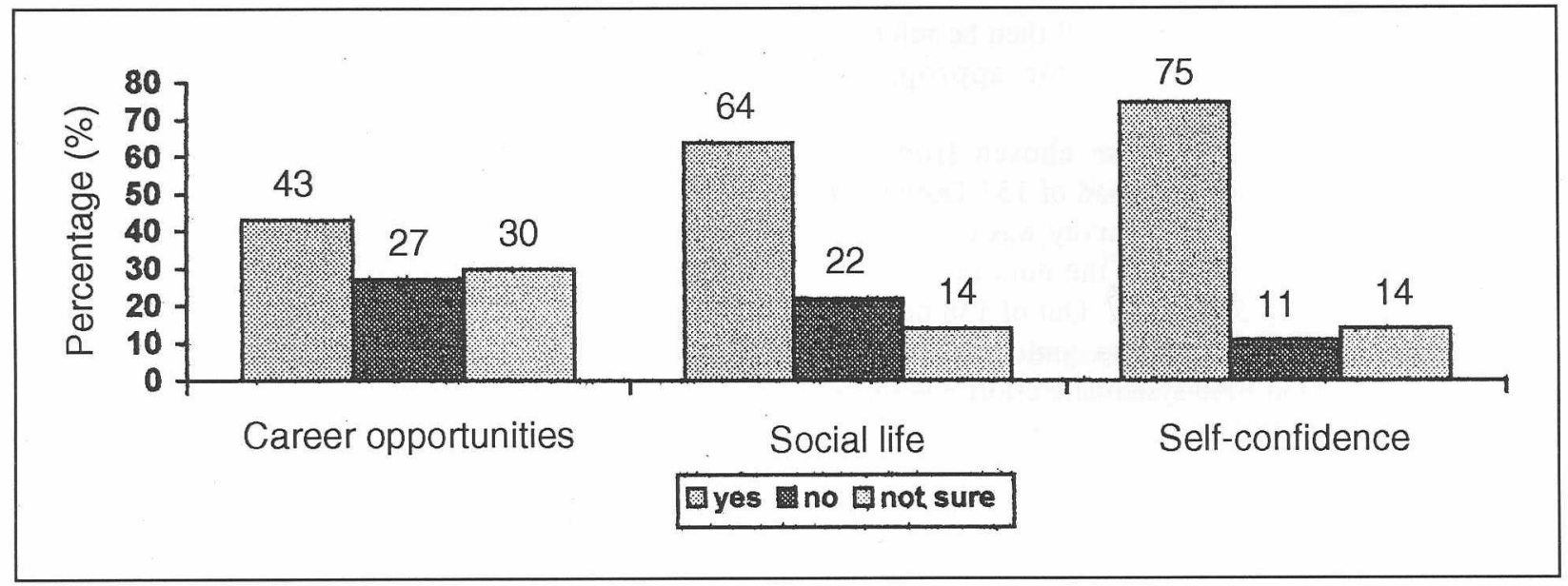

Figure 2: Areas of improvement expected by patients after orthodontic treatment (Part 2 - question 6)

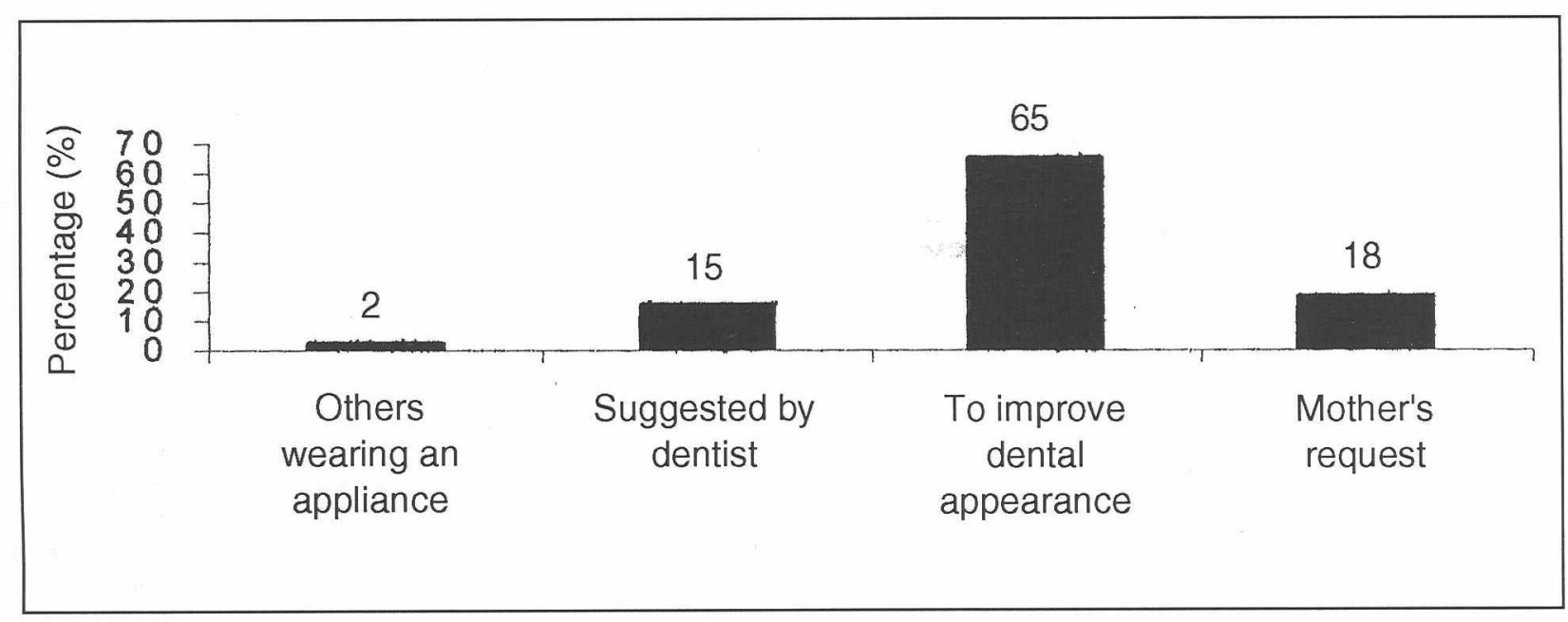

Figure 3: The main reason for seeking orthodontic treatment (Part 2 - question 7)

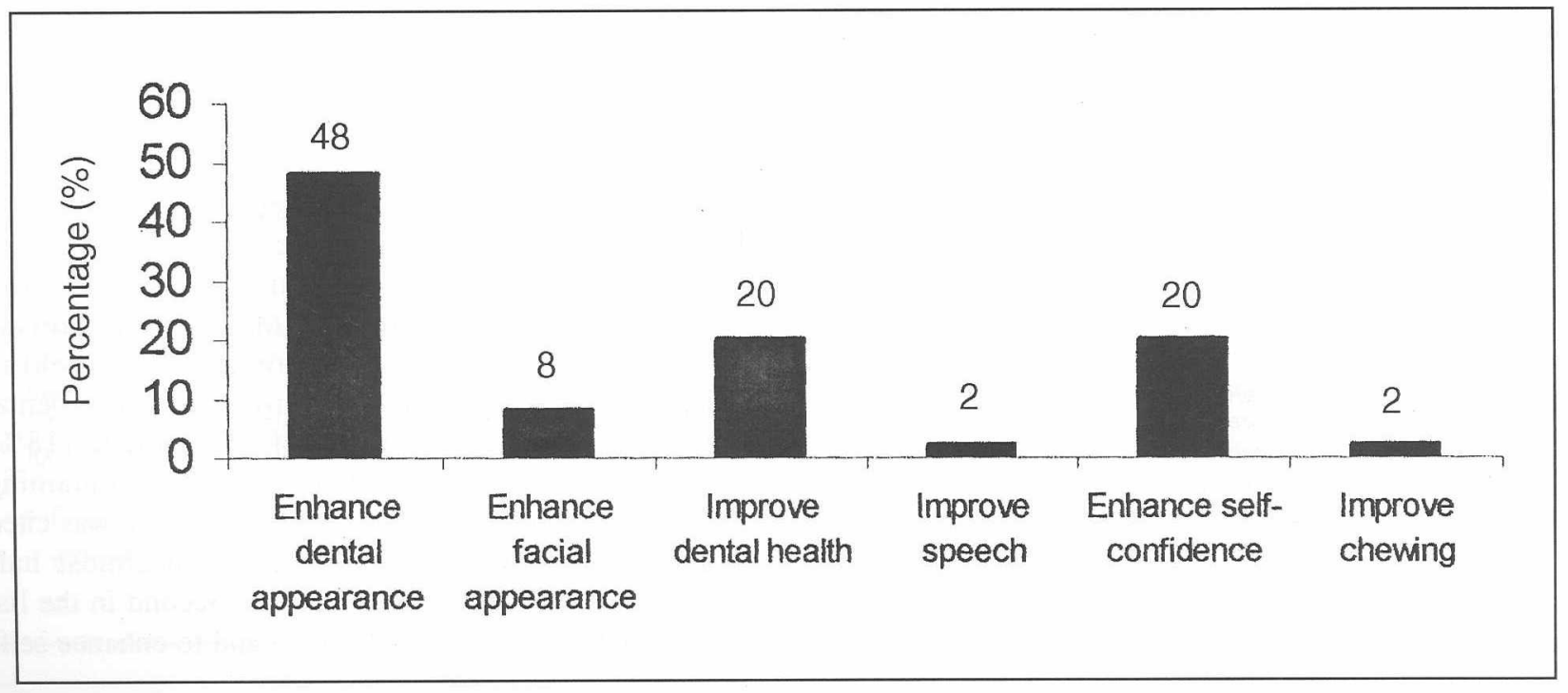

Figure 4: The most important motivating factor in seeking orthodontic treatment (Part 2 - question 8) 


\section{DISCUSSION}

\section{Part 1 - Demographic data \& Dental attendance frequency}

The subjects surveyed in this pilot study represent a convenient sample of the patients that attend the FDUM seeking orthodontic treatment within a 5-month period.

The majority of patients surveyed in our study were females. The same result was also reported in previously published studies such as in Singapore University Hospital where almost 3:1 majority of female respondents (7). These may be a reflection of the fact that standard of aesthetic and beauty is more appreciated by females $(6,7,12)$.

Ingervall \& Hedegard (1974) stated that awareness and desire to receive orthodontic treatment might vary with age (4). Shaw (1981) also stated that decrease in satisfaction with dental appearance is associated with increasing age (6). However, in this study, the majority of patients were adolescents aged between 13-19 years old. This may be because of the psychological changes in teenagers to become more socially acceptable especially in physical attractiveness. Therefore, the desire for orthodontic treatment to enhance attractiveness is higher in this age group.

Malay and Chinese are the two largest ethnic groups in Malaysia, thus making them the majority of patients seeking orthodontic treatment. Most of the patients in our study stated that they visit the dentists only when they have dental problems. This could be due to low dental awareness of the patients surveyed. It is interesting to note that Shaw (1981) in his study found that irregular dental attendance pattern was associated with more dissatisfaction thus leading to higher demand for orthodontic treatment (6). Results from Shaw's study may explain why most of the patients in our study who attend dental clinic only when necessary, have a higher demand for orthodontic treatment.

Part 2 - Dental awareness, psychological effect of malocclusion, sources of referral, motivating factor and main reason for seeking orthodontic treatment.

Most of the participants assessed their appearance as 'average'. This may reflect their desire to improve their unaesthetic dental appearance via orthodontic treatment. Regarding teasing experience, this current study found that most of the patients had no teasing experience. The result disagrees with the study by Shaw (6) in which he reported a high incidence of teasing experience in his sample. Low dental awareness among Malaysians may be one of the reasons why teasing experience is low in the current study, as dental anomalies may appear unnoticeable by other people. In the current study, we also included adults; therefore they may not have any teasing experience or may have forgotten about earlier experiences.

In relation to mirror viewing frequency, Shaw (6) stated that the changing stage from a child to an adolescent would make an individual become more aware of their appearance. His result is similar with that of our pilot survey where most patients themselves were the first to notice their own dental anomalies while mothers were second in place. However, some studies showed that parents were found to have noticed occlusal defects in their children as frequent as dentists have $(5,13)$. Our results differ from those studies possibly due to parental influence, which may not operate directly (5).

Dentists have a large part to play in recommending orthodontic treatment when indicated. However, in this current study, most of the patients surveyed sought orthodontic treatment after having been prompted to do so by friends or family. Only a small percentage sought treatment through recommendation of their dentists. The results of this current study differ from some previously published studies $(5,7,8,12)$. Most of the patients attending Singapore University Hospital were selfreferred (7) while dentists were the largest sources of referral for orthodontic treatment in USA and United Kingdom $(5,8,12)$. The differences may be due to the irregular dental attendance pattern of Malaysian patients thus making the rate of dentists referrals low (7).

Expected improvement in career opportunities, social life and self-confidence following orthodontic treatment were sought by most of the patients. The positive response to changes in career opportunities after orthodontic treatment was lower compared to social life and self-confidence. This may be due to the age of patients surveyed. Most of the patients in this survey were adolescents, making it hard for them to visualise or to evaluate the possible contributions that orthodontic treatment can provide for their future career. Changes in social life and self-confidence can be evaluated readily as patients may have experienced these changes.

Our results showed that attaining straight teeth to improve dental appearance was undoubtedly the most important motivating factor for seeking orthodontic treatment. This was consistent with the findings of Lew (1992) whereby enhancing dental appearance was quoted to be the most important motivating factor for orthodontic treatment amongst Singaporean patients (7). Most studies also demonstrated the same result $(5,7,8)$. The desire to have better dental appearance was the main reason why patients in this current study sought orthodontic treatment. This result is in agreement with most previously published studies $(7,14,15)$.

\section{CONCLUSIONS}

Demographic and psychosocial factors are a few but important ones in leading patients to seek orthodontic treatment. Demographic factors such as age and sex can be considered to have some influences on patients. Most patients seek orthodontic treatment because of a psychological reason, which is to improve their dental appearance and to achieve better aesthetics.

The patient's motivation in seeking orthodontic treatment should be determined before the treatment commences to increase chances for a mutually satisfying result for both dentist/orthodontist and patient. 
However, severity of occlusion as evaluated by the dentists may not correlate with the patients' perception of their dental appearance. We realised that it is also important to justify whether orthodontic treatment should be subjected to any patients when the normative needs do not correlate with the perceived needs of treatment. Therefore, decision in orthodontic intervention should be exercised cautiously when only perceived needs are taken into consideration without assessing the normative needs.

\section{Implication}

This pilot survey can be used as a guide in designing a larger study to represent the Malaysian population. The sample size in this study was small, being a convenient sample of patients listed in the orthodontic waiting list in FDUM for a short period of 5 months. It is recommended that a related future study should encompass larger sample consisting of subjects throughout the country. Sufficient representation of important strata within the Malaysian population such as age, gender, socio-economic background and ethnicity should be included so that a more meaningful outcome can be achieved. As language was one of the barriers in communication during the interview, future studies should consider training interviewers to conduct the survey using four major languages in Malaysia.

Studies looking into the association between demographic data and psychosocial impact of dental anomalies in order to specify the group of patients, which are in real need for orthodontic treatment should be made. Therefore, waiting lists especially in the Government sectors could be shortened if only the identified specific groups are treated.

We suggest that future studies should also look into the association between the clinical severity of dental anomalies that lead to real treatment demand (normative need) and the treatment demanded by patients (perceived need). This present pilot study may be an effort to begin to assess these factors whereby the usage of orthodontic indices such as IOTN may be advocated.

An interesting extension to this study is to do a comparison study on a random population who have dental anomalies and do not seek orthodontic treatment and a specific group of patients who seek orthodontic treatment, in relation to demographic background as well as their perceptions of dental appearance.

\section{Limitations of this study}

Due to the short time frame for the conduct of this survey, only 110 patients could be included, thus they do not represent the general population. Age range, which was between 11-30 years old, was too wide, thus making some of the questions difficult to be understood by younger participants. Questions pertaining to perception of appearance were subjective and hence the response varied from one individual to another. Ranking type of questions could not be posed during a telephone survey because it would be difficult for the participants to remember all the options and rank them at the same time. Difficulties in explaining questions via the telephone were encountered especially when language was also a barrier to some participants who could not understand both English and Malay.

\section{ACKNOWLEDGEMENTS}

We would like to thank Dr. Tuti Ningseh for her advice and suggestions on the design and analysis of this study and Dr. M. Shafeeq for his kind assistance.

\section{REFERENCES}

1. Hotz R. Orthodontic in daily practice. Vienna, Hans Huber Publishers, Bern Stuttgatt 1961.

2. Houston WJB, Stephens CD, Tulley WJ. A textbook of Orthodontics. $2^{\text {nd }}$ Edition. Cambridge, Redwood Books 1993; pp. 6-12.

3. Tayer BH, Burek MJ. A survey of adults' attitudes toward orthodontic therapy. Am J Orthod 1991; 79: 305-315.

4. Ingervall B, Hedegard B. Awareness of malocclusion and desire of orthodontic treatment in 18-year old Swedish men. Acta Odontol Scand 1974; 32: 93-101.

5. Gosney MBE. An investigation into some of the factors influencing the desire for orthodontic treatment. Br J Orthod 1986; 13: 87-94.

6. Shaw WC. Factors influencing the desire for orthodontic treatment. Euro J Orthod 1981; 3: 151162.

7. Lew KK. Attitudes and perceptions of adults towards orthodontic treatment in an Asian community. Community Dent and Oral Epidemiol 1993; 21: 31-35.

8. Breece GL, Nieberg LG. Motivations for adult orthodontic treatment. J Clin Orthod 1986; 20: 166171.

9. Bergstrom K, Halling A, Wilde B. Orthodontic care from the patients' perspective: Perceptions of 27year olds. Euro J Orthod 1998; 20: 319-329.

10. Burden DJ. The influence of social class, genders and peers on the uptake of orthodontic treatment. Euro J Orthod 1995; 17: 199-203.

11. Jenkins PM., Feldman BS, Stirrups DR. The effect of social class and dental features on referrals for orthodontic advice and treatment. $\mathrm{Br} \mathrm{J}$ Orthod 1984; 185-188. 
12. Baldwin DC. Appearance and aesthetics in oral health. Community Dent and Oral Epidemiol 1980; 8: 244-256.

13. Kilpelairen PV, Phillips C, Tullock JF. Anterior tooth position and motivation for early treatment. Angle Orthod 1993; 63: 171-174.
14. Dorsey J, Korabik K. Social and psychological motivations for orthodontic treatment. Am J Orthod (Abstract) 1977; 72: 460.

15. Sheats RD, Gilbert GH, Wheeler TT, King GJ. Pilot study comparing parents' and third-grade schoolchildren's attitudes toward braces and perceived need for braces. Community Dent of Oral Epidemiol 1995; 23: 36-43. 